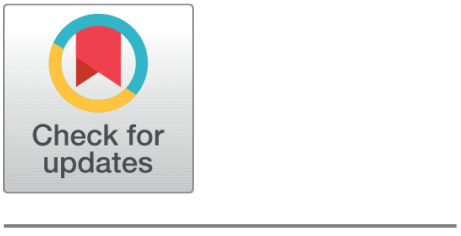

open ACCESS

Received: 09.05.2021

Accepted: 27.08.2021

Published: 27.10 .2021

Citation: Soni M, Sharma RK, Sharma S (2021) The basic reproduction number and herd immunity for COVID-19 in India. Indian Journal of Science and Technology 14(35): 2773-2777. https ://doi.org/10.17485/IJST/v14i35.797

* Corresponding author.

sonimohit895@gmail.com

Funding: None

Competing Interests: None

Copyright: (c) 2021 Soni et al. This is an open access article distributed under the terms of the Creative Commons Attribution License, which permits unrestricted use, distribution, and reproduction in any medium, provided the original author and source are credited.

Published By Indian Society for Education and Environment (iSee)

ISSN

Print: 0974-6846

Electronic: 0974-5645

\section{The basic reproduction number and herd immunity for COVID-19 in India}

\author{
Mohit Soni $^{1 *}$, Rajesh Kumar Sharma ${ }^{1}$, Shivram Sharma ${ }^{2}$ \\ 1 Department of Mathematics, Government Holkar Science College, Indore, M P, India \\ 2 Government P. G. College, Guna, M P, India
}

\section{Abstract}

Objectives: To estimate the basic reproduction number and herd immunity in India relative to the viral disease COVID-19. Methods: In this study, we analyzed literature from March-2020 to January-2021, which were related to the basic reproduction number and herd immunity of COVID-19 in India. Also, we found the mean value of the basic reproduction number and herd immunity as a result. Findings: According to our study, the basic reproduction number and the percentage of the herd immunity ranged from 1.2561 to 3 and from $20 \%$ to $66 \%$, respectively. The mean value of the basic reproduction number and the percentage of the herd immunity is 2.0546 and $51 \%$ respectively. Novelty: To the best of our knowledge, no such studies have been conducted in India.

Keywords: Basic reproduction number; Herd immunity; COVID19; Vaccination; Regression; etc

\section{Introduction}

COVID-19 is a viral disease that has been rampant around the world since its inception. India is also not untouched by COVID-19. Even though the vaccine was produced, the cases of infection are steadily increasing. The higher population density, carelessness of people, lack of medical resources, lack of testing and tracing, are some responsible factors for the coronavirus explosion.

The second wave of the epidemic COVID-19 has caused havoc in India. The first peak of COVID-19 cases was on 16 September 2020. After that, lots of fluctuations came, but from 11 February 2021 (9353 cases), the confirmed cases began to increase. After the 1st confirmed case on 30 January 2020, on 4 April 2021, it crossed the 1 lac mark. ${ }^{(1)}$. Now, on the 13th April 2021, in the number of total confirmed cases, India holds the 1st place in the Asia and the 2nd place in the world ${ }^{(2)}$. The size of the epidemic and the rising statistics of deaths once again forced many states in India to take rigorous and drastic decisions.

Kermack and Mckendrick ${ }^{(3-5)}$ discovered initial SIR (Susceptible, infected, recovered) compartmental model. After that many researchers followed them and made some extended/modified compartmental models such as SIRS (Susceptible, infected, recovered, susceptible), SEIR (Susceptible, exposed, infected, recovered), SEIRS (Susceptible, exposed, infected, recovered, susceptible) SIQR (Susceptible, infected, quarantined, recovered), SIRD (Susceptible, infected, recovered, deaths), ESIR (Extended susceptible, infected, recovered), SAIU (susceptible, asymptomatic, reported symptomatic 
infectious, unreported symptomatic infectious) etc.

The basic reproduction number $\left(R_{0}\right)$ indicates 'the average number of secondary infectious people' generated by an infected person in a completely susceptible population. The dynamics of an epidemic are studied by the researchers and the epidemiologists by applying the compartmental model. $R_{0}$ plays a very important role to control and prevent the spread of a disease. It helps to make strategies and policies against the epidemic. It ensures that if the policies are properly implemented by the government and carefully followed by the citizens, the viral disease can be overcome easily. Levine-Tiefenbrun et al. ${ }^{(6)}$ showed that the vaccination can reduce the value of $R_{0}$.

Balbas L. et al. ${ }^{(7)}$ used the formula that indicates the vaccination percentage required in the population to meet the state of herd immunity. Kadkhoda ${ }^{(8)}$ mentioned that social distancing, mask wearing, and frequent hand washing are important infection prevention measures to control the epidemic COVID-19.

Steven Suan Zhu and Enahoro Iboi ${ }^{(9)}$ estimated $R_{0}$ by using dynamic and statistical modeling. Ives et al. ${ }^{(10)}$ applied timeseries analysis to estimate $R_{0}$. India consists of 28 states and 8 union territories. These states and union territories are further divided into divisions, districts, tehsils, and villages. That's why the value of the basic reproduction number $\left(R_{0}\right)$ can't be determined uniformly or applicable for all regions. It changes between a range. It depends on the various aspects like population density, availability of medical resources, the distribution of different ages into the community, awareness of the people, etc. Gennaro et al. ${ }^{(11)}$ researched the attitude towards COVID-19 vaccination among healthcare professionals in Itali. Awareness and positive attitudes of people can help the government to drive vaccination campaigns successfully.

\section{Method}

The value of $R_{0}$ for COVID-19 is taken from various internet sources such as Google Scholar, MedRxiv, and other online sources. The data are presented in tabular form (see Table 1 ) for analysis of the outcome.

\section{Data}

Data collection is done by Google Scholar and MedRxiv. The keywords "the basic reproduction number for COVID-19 in India" have been searched on various internet sources. After that, 16 research papers were selected, out of which 11 research papers are related to mathematical modeling through the compartment models, 2 research papers are related to the exponential growth method, 1 research paper is related to both the exponential growth method and the epidemic model. The one-one research articles are based on the statistical distribution and the review methodology respectively.

\section{Result and discussion}

The estimated average value of the basic reproduction number $R_{0}$ is 2.0546 that is greater than one and creates a worrying situation for Indian citizens. Although, all the 16 research paper has different methods to estimate the full Di Fi do value of, yet the $R_{0}$ value more than 1.2 in all these research papers indicate a threat to citizens of India. Herd immunity is also interpreted as 'population immunity'. It is the indirect protection against a communicable disease that occurs when a community is protected either by vaccination or by protection obtained by an earlier infection. The W.H.O. (World Health Organization) approvals acquiring 'population immunity' through vaccination, by not permitting the infection to spread into any part of the community, as this may be resulted in the unnecessary patients and deaths. According to John and samuel ${ }^{(12)}$, herd immunity can be measured by testing a sample of the population for the presence of the chosen immune parameter. The percentage of herd immunity is another key factor in controlling the COVID-19 pandemic, which is linked to the basic reproduction number by the relationship:

$$
\text { Herd immunity } \%=\left(1-\frac{1}{R_{0}}\right) \times 100
$$

The range of $R_{0}$ varying from 1.2561 to 3 and so, the value of herd immunity percentage varies from $20 \%$ to $66 \%$ (see table 1 ). 
Table 1. Summary of the study

\begin{tabular}{|c|c|c|c|c|c|c|c|c|}
\hline S.No. & $\begin{array}{l}\text { online } \\
\text { available } \\
\text { date }\end{array}$ & $\begin{array}{l}\text { Date or dura- } \\
\text { tion of the study }\end{array}$ & Data source & Model/method & $\begin{array}{l}\text { Used } \\
\text { software }\end{array}$ & $\begin{array}{l}\text { Estimated } \\
\text { Value of Ro }\end{array}$ & $\begin{array}{l}\text { Herd Immu- } \\
\text { nity } \%\end{array}$ & Reference \\
\hline 1 & $26 / 03 / 2020$ & $\begin{array}{lcc}\text { Data till } & 25 \\
\text { march } & 2020\end{array}$ & $\begin{array}{l}\text { World meter (https://w } \\
\text { ww.worldometers.info/c } \\
\text { oronavirus/) }\end{array}$ & SIR & python & 2.108 & $53 \%$ & (13) \\
\hline 2 & $2 / 4 / 2020$ & $\begin{array}{l}4 \text { march to } 22 \\
\text { march } 2020\end{array}$ & World meter & SEIR & Matlab & 2.28 & $56 \%$ & (14) \\
\hline 3 & $3 / 4 / 2020$ & $\begin{array}{l}30 \text { Jan. to } 30 \\
\text { march }\end{array}$ & John Hopkins university & $\begin{array}{l}\text { SEIR and } \\
\text { regression }\end{array}$ & $\mathrm{R}$ & 2.02 & $50 \%$ & (15) \\
\hline 4 & $6 / 4 / 2020$ & $\begin{array}{l}30 \text { Jan to } 30 \\
\text { March } 2020\end{array}$ & John Hopkins University & $\begin{array}{l}\text { SIR, Expo- } \\
\text { nential, } \\
\text { logistic }\end{array}$ & matlab & 1.504 & $34 \%$ & (16) \\
\hline 5 & $9 / 4 / 2020$ & $\begin{array}{l}2 \text { March to } 7 \\
\text { April } 2020\end{array}$ & World meter/W.H.O. & SIQR & NA & 1.55 & $35 \%$ & (17) \\
\hline 6 & $14 / 04 / 2020$ & $\begin{array}{l}30 \text { Jan. to } 28 \\
\text { march } 2020\end{array}$ & $\begin{array}{l}\text { MoHFW (Ministry } \\
\text { of health and family } \\
\text { welfare) }\end{array}$ & SIR & NA & 2.6 & $62 \%$ & (18) \\
\hline 7 & $14 / 04 / 2020$ & $\begin{array}{l}14 \text { March to } 3 \\
\text { April }\end{array}$ & $\begin{array}{l}\text { MoHFW } \\
\text { /covid19india.org }\end{array}$ & $\begin{array}{l}\text { exponential } \\
\text { growth }\end{array}$ & NA & 2.56 & $61 \%$ & (19) \\
\hline 8 & $17 / 04 / 2020$ & $\begin{array}{l}30 \text { Jan. to } 12 \\
\text { April }\end{array}$ & World meter & SIRD & $\mathrm{R}$ & 2.8 & $64 \%$ & (20) \\
\hline 9 & $9 / 5 / 2020$ & $\begin{array}{l}2 \text { March to } 2 \\
\text { April } 2020\end{array}$ & W.H.O./ MoHFW & SEIR & $\begin{array}{l}\text { earlier } \\
\text { Package }\end{array}$ & 1.471 & $32 \%$ & (21) \\
\hline 10 & $26 / 06 / 2020$ & $\begin{array}{l}1 \text { March to } 7 \\
\text { May }\end{array}$ & NA & $\begin{array}{l}\text { Exponential } \\
\text { growth }\end{array}$ & NA & 1.379 & $27 \%$ & (22) \\
\hline 11 & $29 / 06 / 2020$ & NA & $\begin{array}{l}\text { MoHFW } \\
\text { /W.H.O./covid19india }\end{array}$ & $\begin{array}{l}\text { statistical } \\
\text { distribution }\end{array}$ & NA & 2.6 & $61 \%$ & (23) \\
\hline 12 & $30 / 06 / 2020$ & $\begin{array}{l}30 \text { Jan. to } 14 \\
\text { April }\end{array}$ & John Hopkins university & eSIR & $\mathrm{R}$ & 2 & $50 \%$ & (24) \\
\hline 13 & $5 / 8 / 2020$ & $\begin{array}{l}30 \text { Jan. to } 30 \\
\text { April } 2020\end{array}$ & W.H.O. & SAIU & NA & 1.6632 & $40 \%$ & (25) \\
\hline 14 & $20 / 08 / 20$ & $\begin{array}{l}\text { data till } 30 \text { July } \\
2020\end{array}$ & covid19india.org & SIRD & NA & 1.2561 & $20 \%$ & (26) \\
\hline 15 & $28 / 11 / 2020$ & $\begin{array}{l}4 \text { March to } 25 \\
\text { April }\end{array}$ & covid19india.org & $\begin{array}{l}\text { SEIR Gener- } \\
\text { alized }\end{array}$ & $\mathrm{R}$ & 2.083 & $52 \%$ & (27) \\
\hline 16 & $19 / 01 / 2021$ & NA & NA & Review & NA & 3 & $66 \%$ & (28) \\
\hline
\end{tabular}




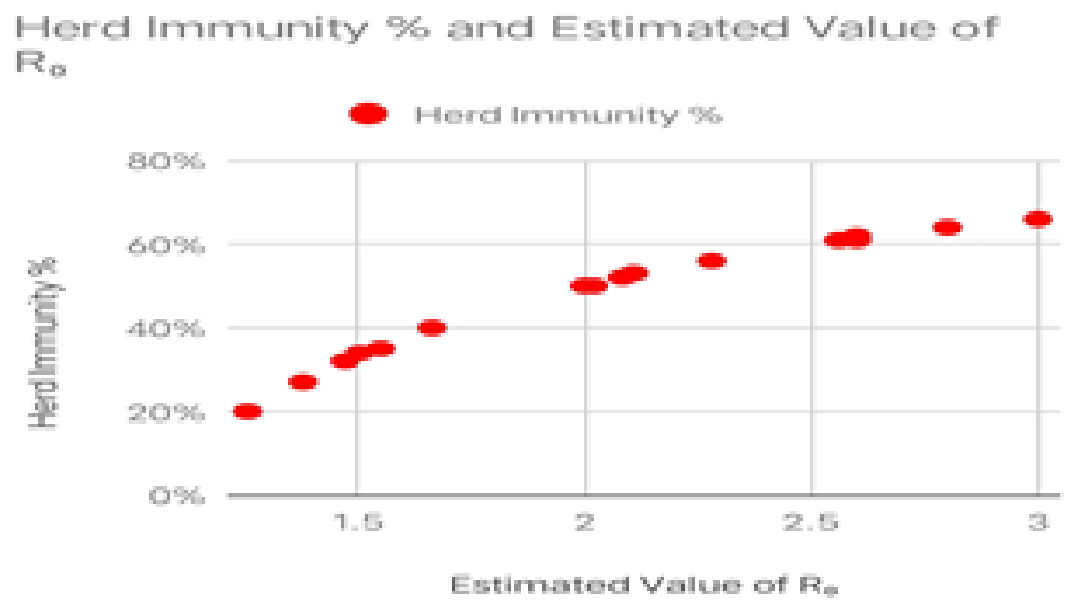

Fig 1. Herd immunity percentage corresponding to the basic reproduction number.

Figure 1 shows the strong regression relationship between the percentage of herd immunity and the percentage required to control emerging COVID-19 viral disease.

\section{Conclusion}

The estimated value of the basic reproduction number $R_{0}$ for COVID-19 in India is in a worrisome state. To reduce the spread of disease, the government of India has to impose all the controlling factors like lockdown/Janta curfew, vaccination, social distancing, wearing masks, frequent hand washing, and improving medical facilities effectively. An average immunization of $51 \%$ of the total population is necessary to reach the state of herd immunity. However, the immunity requirement for the herd must be met to prevent and control the spread of the disease. This survey mainly includes data from 2020 . This study excludes recently published research papers. Thus, in the future, recently published research papers can be included to estimate the basic reproduction number and the percentage of herd immunity.

\section{Conflict of interest}

No conflict of interest exists.

\section{Acknowledgements}

We express our gratitude and very thankful to the editor and both the reviewers for their suggestions to improve our research work.

\section{References}

1) First case of corona virus in Kerala, India. 2020. Available from: https://www.bbc.com/hindi/india-51308206.

2) Worldometer. 2021. Available from: https://www.worldometers.info/coronavirus/country/india/accessedon 14.

3) Kermack W, Ogilvy AG, Mckendrick. Contributions to the mathematical theory of epidemics. II. - The problem of endemicity. In: and others, editor. Proceedings of the Royal Society of London. Series A, Containing Papers of a Mathematical and Physical Character;vol. 138. The Royal Society. 1932;p. 55-83. Available from: https://doi.org/10.1098/rspa.1932.0171.

4) Kermack WO, Mckendrick AG. Contributions to the mathematical theory of epidemics-II. The problem of endemicity. Bulletin of Mathematical Biology. 1991;53(1-2):57-87. Available from: https://doi.org/10.1007/bf02464424.

5) Kermack W, Ogilvy AG, Mckendrick. Contributions to the mathematical theory of epidemics. III.-Further studies of the problem of endemicity. In: and others, editor. Proceedings of the Royal Society of London. Series A, Containing Papers of a Mathematical and Physical Character; vol. 141. The Royal Society. 1933;p. 94-122. Available from: https://royalsocietypublishing.org/doi/10.1098/rspa.1933.0106.

6) Levine-Tiefenbrun M, Yelin I, Katz R, Herzel E, Golan Z, Schreiber L, et al. Initial report of decreased SARS-CoV-2 viral load after inoculation with the BNT162b2 vaccine. Nature Medicine. 2021;27(5):790-792. Available from: https://dx.doi.org/10.1038/s41591-021-01316-7. doi:10.1038/s41591-02101316-7.

7) Balbas LAB, Conesa MG, Balbas BB, Jimenez AA, Caravaca GR. COVID-19 immunization threshold (s): an analysis. medRxiv. 2021. Available from: https://doi.org/10.1101/2021.01.02.20248596. 
8) Kadkhoda K. Herd Immunity to COVID-19. American Journal of Clinical Pathology. 2021;155(4):471-472. Available from: https://dx.doi.org/10.1093/ ajcp/aqaa272. doi:10.1093/ajcp/aqaa272.

9) Zhu SS, Iboi E. 2021. Available from: https://doi.org/10.1101/2021.03.25.21254362.

10) Ives AR, Bozzuto C. Estimating and explaining the spread of COVID-19 at the county level in the USA. Communications Biology. 2021;4(1):60-60. Available from: https://doi.org/10.1038/s42003-020-01609-6.

11) Gennaro FD, Murri R, Segala FV, Cerruti L, Abdulle A, Saracino A, et al. Attitudes towards Anti-SARS-CoV2 Vaccination among Healthcare Workers: Results from a National Survey in Italy. Viruses. 2021;13(3):371-371. Available from: https://dx.doi.org/10.3390/v13030371. doi:10.3390/v13030371.

12) John TJ, Samuel R. Herd immunity and herd effect: new insights and definitions. Eur J Epidemiol. 2000;16(7):601-607. doi:10.1023/a:1007626510002.

13) Singh R, Adhikari R. Age-structured impact of social distancing on the COVID-19 epidemic in India. 2020. Available from: https://arxiv.org/abs/2003. 12055.

14) Chatterjee K, Chatterjee K, Kumar A, Shankar S. Healthcare impact of COVID-19 epidemic in India: A stochastic mathematical model. Medical Journal Armed Forces India. 2020;76(2):147-155. Available from: https://dx.doi.org/10.1016/j.mjafi.2020.03.022. doi:10.1016/j.mjafi.2020.03.022.

15) Pandey G. JMIR Publications Inc.. 2020. Available from: https://arxiv.org/abs/2004.00958.

16) Ranjan R. Predictions for COVID-19 Outbreak in India using epidemiological models. MedRxiv. 2020. Available from: https://doi.org/10.1101/2020.04. 02.20051466

17) Tiwari A. Modelling and analysis of COVID-19 epidemic in India. Journal of Safety Science and Resilience. 2020;1(2):135-140. Available from: https://dx.doi.org/10.1016/j.jnlssr.2020.11.005. doi:10.1016/j.jnlssr.2020.11.005.

18) Bhola J, Venkateswaran VR, Koul M. Corona Epidemic in Indian context: Predictive Mathematical Modelling. MedRxiv. 2020. Available from: https://doi.org/10.1101/2020.04.03.20047175.

19) Rai B, Shukla A, Dwivedi LK. COVID-19 in India: Predictions, Reproduction Number and Public Health Preparedness. MedRxiv. 2020. Available from: https://doi.org/10.1101/2020.04.09.20059261.

20) Rajendrakumar AL, Nair ATN, Nangia C, Chourasia PK, Chourasia MK, Syed MG, et al. Epidemic Landscape and Forecasting of SARSCoV-2 in India. Journal of Epidemiology and Global Health. 2020;11(1):55-55. Available from: https://dx.doi.org/10.2991/jegh.k.200823.001. doi:10.2991/jegh.k.200823.001.

21) Kanagarathinam K, Sekar K. Estimation of Reproduction Number (Ro) and Early Prediction of 2019 Novel Coronavirus Disease (COVID-19) Outbreak in India Using Statistical Computing Approach. Epidemiology and Health. 2020;42:e2020028-e2020028. Available from: https://dx.doi.org/10.4178/epih. e2020028. doi:10.4178/epih.e2020028.

22) Marimuthu S, Joy M, Malavika B, Nadaraj A, Asirvatham ES, Jeyaseelan L. Modelling of reproduction number for COVID-19 in India and high incidence states. Clinical Epidemiology and Global Health. 2021;9:57-61. Available from: https://dx.doi.org/10.1016/j.cegh.2020.06.012. doi:10.1016/j.cegh.2020.06.012.

23) Patrikar SR, Kotwal A, Bhatti VK, Banerjee A, Chatterjee K, Kunte R, et al. Incubation Period and Reproduction Number for novel coronavirus (COVID19) infections in India. MedRxiv. 2020. Available from: https://doi.org/10.1101/2020.06.27.20141424.

24) Ray D, Bhattacharyya, Rupam, Wang, Lili, Mohammed, et al. Predictions, Role of Interventions and Effects of a Historic National Lockdown in India's Response to the the COVID-19 Pandemic: Data Science Call to Arms. Harvard Data Science Review. 2020;2020(Suppl 1). Available from: https://doi.org/10.1162/99608f92.60e08ed5.

25) Samui P, Mondal J, Khajanchi S. A mathematical model for COVID-19 transmission dynamics with a case study of India. Chaos, Solitons \& Fractals. 2020;140:110173-110173. Available from: https://dx.doi.org/10.1016/j.chaos.2020.110173. doi:10.1016/j.chaos.2020.110173.

26) Al-Raeei M. The basic reproduction number of the new coronavirus pandemic with mortality for India, the Syrian Arab Republic, the United States, Yemen, China, France, Nigeria and Russia with different rate of cases. Clinical Epidemiology and Global Health. 2021;9:147-149. Available from: https://dx.doi.org/10.1016/j.cegh.2020.08.005. doi:10.1016/j.cegh.2020.08.005.

27) Gupta M, Mohanta SS, Rao A, Parameswaran GG, Agarwal M, Arora M, et al. Transmission dynamics of the COVID-19 epidemic in India and modeling optimal lockdown exit strategies. International Journal of Infectious Diseases. 2021;103:579-589. Available from: https://dx.doi.org/10.1016/j.ijid.2020.11. 206. doi:10.1016/j.ijid.2020.11.206

28) Khan SF. Herd Immunity in India: A Review. European Journal of Medical and Health Sciences. 2021;3(1):18-21. Available from: https://dx.doi.org/10. 24018/ejmed.2021.3.1.671. doi:10.24018/ejmed.2021.3.1.671. 